\title{
Effect of salinity on performance and body composition of Pacific white shrimp juveniles reared in a super-intensive system
}

\author{
Paula Fraga Maicá1, Maude Regina de Borba ${ }^{2}$, Tatiana Germano Martins ${ }^{1}$, \\ Wilson Wasielesky Junior ${ }^{1}$
}

\footnotetext{
1 Instituto de Oceanografia, Estação Marinha de Aquacultura, Universidade Federal do Rio Grande - Rio Grande, RS, Brasil.

${ }^{2}$ Engenharia de Aquicultura, Universidade Federal da Fronteira Sul - Campus Laranjeiras do Sul, PR, Brasil.
}

\begin{abstract}
The objective of this study was to evaluate the effect of salinity on the culture water quality, performance and body composition of Litopenaeus vannamei juveniles $(1.16 \pm 0.30 \mathrm{~g})$ reared for 36 days in a super-intensive system without water exchange at salinities of 4,16 and $32 \%$. Groups of 200 animals $\left(140 / \mathrm{m}^{2}\right)$ were stocked, with three replicates, in nine fiber-cement tanks $(1.11 \times 1.29 \times 0.70 \mathrm{~m})$ with a useful volume of $400 \mathrm{~L}$. Physical and chemical parameters of water, such as temperature and dissolved oxygen before and after midday, $\mathrm{pH}$, alkalinity, total suspended solids, total ammonium nitrogen, nitrite, nitrate, and phosphate, were monitored. Performance parameters like survival, weight gain, specific growth rate, feed conversion ratio and protein retention rate, were also evaluated. The proximate composition of the juveniles was analyzed through the moisture, protein, lipid and ash contents. The physical and chemical parameters of the water were influenced by the treatments. The increased salinity produced a significant increase in the alkalinity and the concentrations of total suspended solids, nitrite and phosphate. Of the parameters that were examined to evaluate the performance and proximate composition of the shrimp, only survival, protein retention rate and body lipid content were significantly influenced. The highest values were found at a salinity of $32 \%$. However, the analysis of the proximate composition of the bioflocs showed that the moisture, protein and lipid contents increased as the salinity decreased. Growth, use of feed and survival of L. vannamei juveniles reared in a super-intensive system without water exchange is positively influenced by an increase of salinity from 4 to $32 \%$.
\end{abstract}

Key Words: bioflocs, Litopenaeus vannamei, proximate composition, zero-water-exchange system

\section{Introduction}

The Pacific white shrimp (Litopenaeus vannamei) is the most widely reared penaeid in the Western Hemisphere (Saoud et al., 2003). Due to its ability to maintain osmotic regulation over a wide range of salinities, this species is capable of inhabiting waters with salinities ranging from 0.5 to $40 \%$ (Saoud et al., 2003). However, although $L$. vannamei juveniles can be successfully reared at salinities of 5 to $35 \%$ (Ponce-Palafox et al., 1997), the salinity range considered ideal for the culture of the species is from 15 to 25\% (Boyd, 1989).

The excellent animal-performance characteristics of L. vannamei, together with its tolerance of a wide range of salinities, have made this species attractive for culture at low salinities in several American countries (McGraw et al., 2002), Thailand (Saoud et al., 2003), Israel (Boyd, 2001) and China (Cheng et al., 2006). The production of marine

Received August 2, 2013 and accepted March 20, 2014 Corresponding author: mau.b@live.com

http://dx.doi.org/10.1590/S1516-35982014000700001

Copyright (@) 2014 Sociedade Brasileira de Zootecnia. This is an Open Access article distributed under the terms of the Creative Commons Attribution Non-Commercial License, which permits unrestricted non-commercial use, distribution, and reproduction in any medium, provided the original work is properly cited. shrimp in inland waters is more economically viable than marine shrimp culture in coastal zones due to the high cost of land and the strict environmental protection legislation in these coastal regions (Atwood et al., 2003). In addition, the inland culture of marine shrimp allows the shrimp farms to be located at a distance from potentially contaminated coastal waters (Moya et al., 1999). However, reduced salinities may affect the physiology of marine shrimp, resulting in decreased survival (Jiang et al., 2000).

In recent years, growing concerns about the environmental impact of shrimp farms, together with the incidence of diseases, spurred the development of culture systems using minimum or no water exchange (Hopkins et al., 1995). These systems minimize the discharge of effluent (Naylor et al., 1998) and the probability of the spread of pathogens (Wasielesky et al., 2006). Moreover, the characteristic microbial community of these systems (bioflocs) may represent a supplemental dietary source for the reared organisms (Burford et al., 2004), allowing a decrease in the concentration of the feed protein (Ballester et al., 2010).

Thus, in view of the advantages in producing marine shrimp in inland waters in biofloc systems, this study aimed to evaluate the influence of salinity on the culture water quality, performance and body composition of $L$. vannamei 
juveniles reared in a super-intensive system without water exchange.

\section{Material and Methods}

This study was conducted at the facilities of the Marine Station of Aquaculture Prof. Marcos Alberto Marchiori (EMA), Institute of Oceanography, Universidade Federal do Rio Grande, located in Rio Grande/RS, Brazil. The shrimp larvae were acquired from the commercial laboratory Aqualíder Ltda (Porto de Galinhas/PE, Brazil). After the arrival of the L. vannamei nauplii at the EMA facilities, the nauplii were kept in the Sector of Marine Shrimp Larviculture $\left(28^{\circ} \mathrm{C}, 30 \%\right.$ ) and reared according to methodology adapted from Marchiori (1996) until their use in the experiment. The experimental system was located inside a greenhouse and consisted of nine fiber-cement tanks $(1.11 \times 1.29 \times 0.70 \mathrm{~m})$ with a useful volume of $400 \mathrm{~L}$.

Prior to the transfer of the $L$. vannamei juveniles to the experimental units, the animals were properly acclimated to the different salinities $(4,16$ and $32 \%$ ) to be evaluated. The shrimp were stocked in 163-L polyethylene tanks with a bottom area of $0.36 \mathrm{~m}^{2}$. Over seven days, $5 \%$ reductions in salinity were performed every $24 \mathrm{~h}$ until the desired salinity was reached (Ponce-Palafox et al., 1997). The shrimp were cultured in different salinities obtained by diluting previously chlorinated ( $15 \mathrm{~mL}$ chlorine/1,000 L) and, then, dechlorinated seawater with dechlorinated freshwater from the public supply.

To prepare the culture medium, the experimental units were filled with water at the different salinities. The diatom Thalassiosira weissflogii, an euryhaline species, able to acclimate to extreme salinity environments, from freshwater - brackish, to marine waters (Radchenko and Il'yash, 2005), was then inoculated in each tank at an approximate concentration of $1.75 \times 10^{4}$ cells $/ \mathrm{mL}$. When the phase of exponential growth of the microalgae was verified (approximately 3 days after the inoculation), the shrimp were stocked. Groups of 200 L. vannamei juveniles $\left(140 / \mathrm{m}^{2}\right)$ with an initial weight of $1.16 \pm 0.30 \mathrm{~g}$, properly acclimated to the 4,16 and $32 \%$ salinities, were stocked in the experimental units. During the 36 days of the experiment, the shrimp were fed a commercial diet ( $44.5 \%$ crude protein) supplied in trays $(Q=0.15 \mathrm{~m})$ twice a day $(9.00 \mathrm{~h}$ and $17.00 \mathrm{~h})$. The initial feeding rate was $7 \%$ of the total biomass in each experimental unit, adjusted according to the amount of unconsumed feed measured in the culture each day. Every morning, uneaten feed was removed from the feeding trays and dried in an oven at 70 ${ }^{\circ} \mathrm{C}$ until a constant weight was attained. The final dry weight was then recorded to the nearest $0.01 \mathrm{~g}$. In addition, feed leaching and percent moisture were evaluated according to Wasielesky et al. (2006).

To stimulate the formation of the microbial floc, the water in the experimental tanks was strongly aerated by airlift devices and was fertilized during the first three experimental days with molasses and wheat bran as carbon sources. The nominal C:N ratio of the daily additions of organic matter to the tank was approximately 20:1 based on the carbon and nitrogen concentration in the commercial diet and organic fertilizers (Chamberlain et al., 2001). Thereafter, organic matter was added according to the TA-N concentration in the system. When concentrations of TA-N $\geq 1 \mathrm{mg} / \mathrm{L}$ were found, molasses was added at a ratio of $6 \mathrm{~g}$ carbon to each $1 \mathrm{~g}$ TA-N (Avnimelech, 1999).

The salinity, temperature, dissolved oxygen content $\left(\mathrm{DO}_{2}\right)$ and $\mathrm{pH}$ of the water were monitored daily with a multiparameter equipment (YSI ${ }^{\circledR}$ - Ohio/USA). Every three days, water samples were collected for the determination of TA-N using the UNESCO (1983) methodology and for nitrite $\left(\mathrm{N}-\mathrm{NO}_{2}{ }^{-}\right)$, nitrate $\left(\mathrm{N}-\mathrm{NO}_{3}{ }^{-}\right)$and phosphate $\left(\mathrm{P}-\mathrm{PO}_{4}{ }^{3-}\right)$ determination according to Aminot and Chaussepied (1983). The concentration of total suspended solids (TSS) was also evaluated every three days with a method adapted from Strickland and Parsons (1972), and alkalinity was verified weekly with the Titrimetric method (APHA, 1989).

Random samples of 20 shrimp from each experimental unit were briefly dried with a paper towel and then weighed at the beginning of the study, on the 20th day and at the end of the study, when the quantitative characteristics of all the shrimp were measured.

Samples of approximately $50 \mathrm{~g}$ of shrimp from the initial stock and $150 \mathrm{~g}$ of shrimp from each salinity level ( $50 \mathrm{~g} / \mathrm{tank}$ ) were collected at the beginning and the end of the experiment, respectively, for the analysis of whole body composition (AOAC, 1999). The L. vannamei juveniles were sacrificed with hypothermia and stored $\left(-20{ }^{\circ} \mathrm{C}\right)$ until analysis. At the end of the trial, samples of the bioflocs formed at each salinity level were also collected for proximate composition analysis. It was necessary to pool the replicates at each salinity concentration to obtain a sufficient quantity of material for analysis.

The performance and nutrient retention of the shrimp were evaluated in terms of the following parameters:

Survival $(\%)=($ shrimp initial number - dead shrimp number $) /$ shrimp initial number $\times 100$;

Weight gain $(\mathrm{g})(\mathrm{WG})=$ final weight $(\mathrm{g})-$ initial weight $(\mathrm{g})$;

Specific growth rate $(\%)(\mathrm{SGR})=100 *(\ln$ final weight (g) - $\ln$ initial weight (g))/days of experiment; 
Feed conversion ratio $(\mathrm{FCR})=$ feed intake (dry matter) (g)/weight gain (g); and

Protein retention rate $(\%)(\mathrm{PRR})=(($ final weight $(\mathrm{g}) *$ final body protein $(\%))$ - (initial weight $(\mathrm{g}) \times$ initial body protein $(\%)) /$ total protein intake $($ dry matter $) \times 100$

The homoscedasticity of the variances and the normality of the data on the physical and chemical parameters of the water, performance and proximate composition of the shrimp were verified. A one-way analysis of variance (ANOVA) was then applied. If significant differences $(\mathrm{P}<0.05)$ among treatments were detected, the means were compared with a Tukey HSD test. The values expressed in percentages were arcsine transformed for the analysis (Sokal and Rohlf, 1969).

\section{Results}

The temperature, $\mathrm{DO}_{2}$ concentration in the morning and $\mathrm{pH}$ did not differ significantly $(\mathrm{P}>0.05)$ among the treatments (Table 1). However, the $\mathrm{DO}_{2}$ concentration recorded in the afternoon was significantly lower $(\mathrm{P}<0.05)$ at the $32 \%$ salinity. The alkalinity, TSS and $\mathrm{P}_{-} \mathrm{PO}_{4}{ }^{3-}$ concentrations increased with increasing salinity and were significantly higher $(\mathrm{P}<0.05)$ at $32 \%$. The nitrogen compounds showed no significant differences $(\mathrm{P}>0.05)$. However, the TA-N concentration tended to decrease and the $\mathrm{N}_{-} \mathrm{NO}_{3}^{-}$concentration tended to increase with increasing salinity. The ${\mathrm{N}-\mathrm{NO}_{2}-}^{-}$concentration increased with increasing salinity and was significantly higher at $32 \%$.

The highest survival was verified at a salinity of $32 \%$. This value of survival differed significantly $(\mathrm{P}<0.05)$ from that obtained at the 4 and $16 \%$ salinities (Table 2). Although no significant differences $(\mathrm{P}>0.05)$ were found in weight gain, specific growth rate or feed conversion of the shrimp maintained at the different salinities, these parameters tended to improve with the increase in salinity. The protein retention rate showed a direct positive relationship with the increase in salinity and was significantly higher in the shrimp maintained at $32 \%$.

The data on the whole-body composition of the shrimp (Table 3) showed a tendency for moisture to decrease and for protein and ash content to increase with increasing salinity, but these differences were not significant $(\mathrm{P}>0.05)$. However, the body lipid content of the $L$. vannamei juveniles was significantly $(\mathrm{P}<0.05)$ influenced by the salinity. The lowest and highest values found for the shrimp occurred at 4 and $32 \%$, respectively.

The proximate composition of the bioflocs suggested that the salinity had little influence on the moisture, protein and lipid contents, which showed only a small variation. However, the ash content increased as the salinity increased from 4 to 16 and $32 \%$.

Table 1 - Physical and chemical parameters of the water of L. vannamei culture in super-intensive system without water exchange at different salinities for 36 days $^{1}$

\begin{tabular}{|c|c|c|c|c|}
\hline Parameters & $4 \%$ & $16 \%$ & $32 \%$ & P-value \\
\hline Temperature a.m. $\left({ }^{\circ} \mathrm{C}\right)$ & $23.29 \pm 0.20$ & $22.92 \pm 0.66$ & $22.93 \pm 0.32$ & 0.314 \\
\hline Temperature p.m. $\left({ }^{\circ} \mathrm{C}\right)$ & $23.10 \pm 0.14$ & $22.84 \pm 0.52$ & $22.89 \pm 0.28$ & 0.574 \\
\hline Dissolved oxygen a.m. (mg/L) & $6.53 \pm 0.07$ & $6.28 \pm 0.19$ & $5.73 \pm 0.17$ & 0.281 \\
\hline Dissolved oxygen p.m. (mg/L) & $6.83 \pm 0.16 \mathrm{a}$ & $6.57 \pm 0.12 \mathrm{a}$ & $6.07 \pm 0.17 b$ & 0.001 \\
\hline $\mathrm{pH}$ & $7.85 \pm 0.02$ & $7.83 \pm 0.02$ & $7.99 \pm 0.02$ & 0.281 \\
\hline Alkalinity $\left(\mathrm{mg} \mathrm{CaCO}_{3} / \mathrm{L}\right)$ & $76.86 \pm 3.61 b$ & $95.48 \pm 1.64 b$ & $150.95 \pm 8.46 \mathrm{a}$ & 0.000 \\
\hline Total suspended solids (mg/L) & $344.61 \pm 22.13 b$ & $483.58 \pm 35.53 \mathrm{ab}$ & $743.00 \pm 28.39 \mathrm{a}$ & 0.001 \\
\hline Total ammonium nitrogen $(\mathrm{mg} / \mathrm{L})$ & $3.98 \pm 0.35$ & $2.92 \pm 0.57$ & $1.75 \pm 1.05$ & 0.079 \\
\hline Nitrite $(\mathrm{mg} / \mathrm{L})$ & $2.71 \pm 0.71 b$ & $4.81 \pm 1.51 \mathrm{ab}$ & $7.11 \pm 1.13 \mathrm{a}$ & 0.002 \\
\hline Nitrate (mg/L) & $8.14 \pm 0.16$ & $8.45 \pm 0.22$ & $10.13 \pm 0.84$ & 0.762 \\
\hline Phosphate (mg/L) & $0.29 \pm 0.10 b$ & $0.47 \pm 0.06 \mathrm{ab}$ & $0.60 \pm 0.06 \mathrm{a}$ & 0.001 \\
\hline
\end{tabular}

${ }^{1}$ Mean of 3 replicates \pm SD. In the row, different letters indicate significant differences $(\mathrm{P}<0.05)$.

a.m. - before midday; p.m. - after midday.

Table 2 - Performance of L. vannamei juveniles reared in super-intensive system without water exchange at different salinities for 36 days ${ }^{1,2}$

\begin{tabular}{|c|c|c|c|c|}
\hline Parameters & $4 \%$ & $16 \%$ & $32 \%$ & P-value \\
\hline Survival (\%) & $74.8 \pm 4.93 b$ & $72.8 \pm 4.65 b$ & $88.3 \pm 0.58 \mathrm{a}$ & 0.003 \\
\hline Weight gain $(\mathrm{g})$ & $0.98 \pm 0.39$ & $1.06 \pm 0.46$ & $1.81 \pm 0.28$ & 0.072 \\
\hline Specific growth rate $(\%)$ & $2.14 \pm 0.48$ & $2.26 \pm 0.58$ & $2.74 \pm 0.25$ & 0.316 \\
\hline Feed conversion ratio & $2.23 \pm 0.60$ & $2.45 \pm 1.27$ & $1.07 \pm 0.14$ & 0.054 \\
\hline Protein retention rate $(\%)$ & $28.31 \pm 4.78 b$ & $32.84 \pm 0.77 \mathrm{ab}$ & $42.07 \pm 6.11 \mathrm{a}$ & 0.003 \\
\hline
\end{tabular}

${ }^{1}$ Initial weight: $1.16 \pm 0.30 \mathrm{~g}$ (mean $\left.\pm \mathrm{SD}\right)$.

${ }^{2}$ Mean of 3 replicates \pm SD. In the row, different letters indicate significant differences $(\mathrm{P}<0.05)$. 
Table 3 - Proximate composition of L. vannamei juveniles reared in super-intensive system without water exchange at different salinities and bioflocs obtained after 36 days ${ }^{1,2}$

\begin{tabular}{|c|c|c|c|c|}
\hline \multirow{2}{*}{ Salinities (\%o) } & Moisture & Protein & Lipid & Ash \\
\hline & \multicolumn{4}{|c|}{$(\mathrm{g} / \mathrm{kg})$} \\
\hline & \multicolumn{4}{|c|}{ Shrimp } \\
\hline 4 & $796.9 \pm 18.1$ & $156.5 \pm 12.9$ & $07.7 \pm 02.7 \mathrm{~b}$ & $27.5 \pm 01.3$ \\
\hline 16 & $781.3 \pm 11.6$ & $167.1 \pm 08.3$ & $10.0 \pm 01.5 \mathrm{ab}$ & $30.6 \pm 02.9$ \\
\hline \multirow[t]{2}{*}{32} & $779.0 \pm 05.0$ & $169.6 \pm 05.1$ & $13.8 \pm 01.7 \mathrm{a}$ & $31.9 \pm 01.1$ \\
\hline & \multicolumn{4}{|c|}{ Bioflocs $^{3}$} \\
\hline 4 & 901.8 & 34.4 & 04.2 & 13.4 \\
\hline 16 & 884.4 & 30.2 & 03.3 & 25.7 \\
\hline 32 & 891.5 & 28.4 & 03.4 & 44.5 \\
\hline
\end{tabular}

${ }^{1}$ Values expressed with base on the wet matter. Initial centesimal composition (g/kg): moisture 805.7; protein 147.0; lipid 07.9 and ash 34.1.

${ }^{2}$ Mean of 3 replicates \pm SD. In the row, different letters superscript indicate significant differences $(\mathrm{P}<0.05)$.

${ }^{3}$ A pool of samples of the three replicates of each salinity level was made for the analysis.

\section{Discussion}

The temperature of the culture was slightly below the range of 24 to $32{ }^{\circ} \mathrm{C}$ considered appropriate for the culture of the species. This lower temperature tended to decrease the growth potential of the shrimp from its maximum potential (Van Wyk and Scarpa, 1999). Wyban et al. (1995) reported that $L$. vannamei juveniles $(3.9 \mathrm{~g})$ showed reduced growth at a temperature of $23{ }^{\circ} \mathrm{C}$ compared with the growth of the same-size class reared at 27 and $28{ }^{\circ} \mathrm{C}$. The $\mathrm{DO}_{2}$ concentration showed a slight decreasing trend with the increase in salinity but remained within the recommended range (5.0-9.0 $\mathrm{mg} / \mathrm{L}$ ) for the species. The $\mathrm{pH}$ also remained in the range considered appropriate for good performance of penaeid shrimp (7.0-9.0) (Van Wyk and Scarpa, 1999; Cohen et al., 2005). According to Van Wyk and Scarpa (1999), an alkalinity $\geq 100 \mathrm{mg} / \mathrm{L} \mathrm{CaCO}_{3}$ is recommended for the culture of penaeids. Values in this range were only reached at $32 \%$ despite the gradual increase of alkalinity with the increase in salinity.

The evaluation of the TSS concentration showed an increase in the density of the bioflocs over the experimental period. This concentration was directly influenced by the salinity and showed its highest value at 32\%. Decamp et al. (2003) also found the highest TSS concentration at the highest salinity (36\%). These results are supported by the findings of other studies, whose authors remark that the salinity and temperature are factors that influence the concentration of the bioflocs. A tendency for the aggregation of the suspended particles and the size of the bioflocs to increase with the increase in salinity was also verified (Hakanson, 2006; Avnimelech, 2007).

The lowest TA-N concentration was recorded at the highest salinity. However, the differences in TA-N were not significant. Decamp et al. (2003) state that in culture systems without water exchange, the dynamics of nitrogen does not appear to be significantly impacted by the salinity. These researchers suggest that the variations in the concentrations of nitrogen compounds observed at different salinities reflect only the nitrogen accumulation in a culture system maintained without water exchange. However, many studies indicate that salinity represents one of the major factors influencing the development of heterotrophic bacteria and the nitrification processes (Timmons et al., 2002). Moreover, these studies have demonstrated an inverse relationship between salinity and the rates of TA-N excretion by penaeid shrimp (Gómez-Jiménez et al., 2005; Perez-Velazquez et al., 2008). The highest $\mathrm{N}_{-} \mathrm{NO}_{2}^{-}$and $\mathrm{N}-\mathrm{NO}_{3}{ }^{-}$concentrations were found at the highest salinity, suggesting a higher intensity of the nitrification processes. The $\mathrm{N}^{-\mathrm{NO}_{3}}{ }_{3}^{-}$concentration tended to increase with increasing salinity. However, this parameter was below the maximum level recommended for the species $(\leq 60 \mathrm{mg} / \mathrm{L})$ (Van Wyk and Scarpa, 1999) in all treatments. Decamp et al. (2003) also verified an increase in the $\mathrm{N}^{-\mathrm{NO}_{3}}{ }^{-}$concentration with increasing salinity in L. vannamei culture without water exchange. Lin and Chen (2003) demonstrated an inverse relationship between salinity and $\mathrm{N}^{-\mathrm{NO}_{2}}{ }_{2}^{-}$toxicity in L. vannamei juveniles, observing that the susceptibility to this substance increased if the animals were exposed to hypo-osmotic conditions. The $\mathrm{N}^{-\mathrm{NO}_{2}-}$ concentration exceeded the safe concentrations for the culture of $L$. vannamei juveniles in seawater $(\leq 1 \mathrm{mg} / \mathrm{L})$ and water with salinity close to $2 \% 0(0.45 \mathrm{mg} / \mathrm{L})$ (Van Wyk and Scarpa, 1999; Gross et al., 2004). Thus, is possible that the $\mathrm{N}^{-\mathrm{NO}_{2}}$ concentrations in the cultures contributed to mortality, which increased significantly at salinities lower than $32 \%$. The $\mathrm{P}_{-} \mathrm{PO}_{4}^{3-}$ concentration was directly related to and significantly influenced by increasing salinity. Similarly, Decamp et al. (2003) found that the $\mathrm{P}^{-} \mathrm{PO}_{4}{ }^{3-}$ concentration 
tended to increase with increasing salinity. In excavated culture ponds, phosphate ions are rapidly bound by the sediment, and the concentration of these ions in the water column decreases substantially (Boyd, 2007). However, phosphate accumulation in the culture is expected in ponds with a lined bottom and in recirculating closed systems, as observed in this study.

In general, the survival observed in culture systems without water exchange and in association with bioflocs is high (McAbee et al., 2003; Wasielesky et al., 2006; Kuhn et al., 2008). However, the survival of marine shrimp reared at low salinities varies and may be influenced by factors such as the ionic composition of the water, the species, the age of the animals, the rate of reduction of salinity and the final salinity at which acclimation occurs (McGraw et al., 2002; Cheng et al., 2006). In this study, shrimp survival was significantly affected by salinity, with increasing mortality as the salinity decreased from 32 to 16 and $4 \%$. Similar effects were reported by Laramore et al. (2001) with $L$. vannamei post-larvae at salinities of 4 and 30\% (survival of 86 and $100 \%$, respectively); Jayasankar et al. (2009), with post-larvae at salinities of $0.0,0.5,0.75$ and $1.5 \%$ (survival of 2, 29, 47 and $85 \%$, respectively) and juveniles at salinities of $0.0,0.5$ and $0.75 \%$ (survival of 65,77 and $93 \%$, respectively); Decamp et al. (2003), with juveniles, in a system without water exchange, at salinities of 9, 18 and 36\% (survival of 68, 93 and 94\%, respectively); and Maicá et al. (2012), with juveniles, in the same system, at salinities of 2, 4 and $25 \%$ (survival of $22.50,72.73$ and $97.50 \%$, respectively). Moreover, Perez-Velazquez et al. (2012) observed a reduced value of survival of $L$. vannamei post-larvae reared at a water temperature of $24{ }^{\circ} \mathrm{C}$, at a salinity level of $4 \%$ and with a $\mathrm{Na}^{+}: \mathrm{K}^{+}$ratio of 120 (10.0\%), compared with the 40 (95\%).

According to Cheng et al. (2005), L. vannamei juveniles reared at low salinities gain less weight than those maintained in seawater. In this study, the decreased salinity was reflected in a decrease in shrimp growth confirmed by a decreasing trend in specific growth rate and weight gain. Although the differences were not statistically significant, the results were informative because the weight gain attained at $4 \%$ (coefficient of variation 0.40 ) salinity was almost half of that obtained at $32 \%$ (coefficient of variation 0.16 ). Laramore et al. (2001), Walker et al. (2009), and Maicá et al. (2012), also in a system without water exchange, likewise recorded higher weight gains for both L. vannamei postlarvae and juveniles maintained at high salinity (at 30, 28 and $25 \%$, respectively), than at low salinity (at 4,2 and $2 \%$, respectively). Furthermore, Perez-Velazquez et al. (2012) reported a reduced value of weight gain of the referred species post-larvae reared in a water temperature of $24{ }^{\circ} \mathrm{C}$, at salinity of $4 \%$ and with a $\mathrm{Na}^{+}: \mathrm{K}^{+}$ratio of $120(514.0 \%)$, compared with that of $40(1,212.8 \%)$. Saoud et al. (2003) explain that the ionic composition of well waters may be a more important limiting factor to the shrimp growth and survival than the salinity itself. Deficiencies in certain ions, such as magnesium $\left(\mathrm{Mg}^{2+}\right)$ and potassium $\left(\mathrm{K}^{+}\right)$, have been shown to negatively impact growth and survival of shrimp (Saoud et al., 2003; Davis et al., 2005). Moreover, according to Roy et al. (2007) there are indications that the sodium $\left(\mathrm{Na}^{+}\right)$and $\mathrm{K}^{+}$ratio of low salinity waters may be a critical factor for the successful shrimp growth and survival; as could be seen, for example, in the mentioned study of Perez-Velazquez et al. (2012). Besides this, Rosas et al. (2001) state that marine shrimp reared at low salinity use dietary protein as a source of amino acids for not only weight gain (protein retention) but also maintenance of osmotic pressure. In this context, certain studies demonstrate that marine shrimp maintained at salinity lower than that of seawater shrimp exhibit a higher protein requirement (Shiau, 1998). However, Perez-Velazquez et al. (2008), rearing $L$. vannamei juveniles at $4 \%$ salinity in a system without water exchange, did not observe significant differences in the weight gain of shrimp fed diets with 35 and 40 , or 25 and $30 \%$ CP. Similarly, Perez-Velazquez et al. (2007), maintaining juveniles of the same species at 2, 35, and $50 \%$ and feeding them diets with $25,30,35$ and $40 \%$ $\mathrm{CP}$, found no significant effect of the interaction between salinity and protein concentrations on the weight gain of the shrimp. Wasielesky et al. (2006) remark that the weight gain of shrimp reared in systems without water exchange in association with bioflocs increases due to the nutritional benefits provided by the high natural productivity characteristic of these environments.

Feed conversion was not significantly influenced by salinity but tended to improve with increasing salinity. This result is consistent with the findings of Decamp et al. (2003), who did not find significant differences among the feed conversion values of L. vannamei juveniles maintained at 9,18 and $36 \%$ but reported lower (better) values of feed conversion with increasing salinity (7.9, 1.8 and 1.6, respectively). In this study, the improvement in feed utilization with increasing salinity was also demonstrated by a significant increase in the protein retention rate of shrimp reared at 32\% compared with shrimp maintained at $4 \%$ and $16 \%$.

Huang et al.(2004) state that the biochemical composition (moisture, lipids and protein) of penaeid shrimp varies with changes in salinity. In this study, although the moisture content did not significantly differ among the salinities, it tended to decrease as the salinity increased. Similarly, Liang et al. (2008) and Perez-Velazquez et al. (2007) found 
an increase in the moisture content of $L$. vannamei juveniles as the salinity decreased from 30 to $0.5-1.5 \%$ (moisture contents of 747.0 and $807.0 \mathrm{~g} / \mathrm{kg}$, respectively) and from 50 to $2 \%$ ( 708.0 and $737.0 \mathrm{~g} / \mathrm{kg}$, respectively). In contrast, $\mathrm{Li}$ et al. (2007) observed a direct relationship between the moisture content of L. vannamei juveniles (735.0, 750.0 and $767.0 \mathrm{~g} / \mathrm{kg}$ ) and increase in salinity $(3,17$, and $32 \%$ ).

The body content of protein, lipids, and ash in the shrimp increased from the lowest to the highest tested salinity, but the differences were significant only for lipids. Studies conducted by Huang et al. (2004) and Liang et al. (2008) demonstrated a similar salinity effect on the protein content of L. vannamei. However, although Li et al. (2007) and Perez-Velazquez et al. (2007) did not find a significant influence, they found that the body protein content of $L$. vannamei juveniles decreased with increasing salinity, a result contradicting that obtained by the current study. The findings of Li et al. (2007) and Liang et al. (2008) for the contents of lipids and ash were also unlike those of the current study. Those authors reported a decrease in the lipid and ash content of $L$. vannamei juveniles according to the increase in salinity, but the differences were not significant.

The protein content of the bioflocs tended to increase with decreasing salinity. Similar results were reported by Ju et al. (2008), who reared L. vannamei juveniles in a system with reduced water exchange at 5, 18, and 32\%o salinity and found that the bioflocs formed at the lowest salinity showed a higher protein content than the bioflocs formed at the highest salinity. The literature reports a variety of findings about lipid content in bioflocs. In this study, the lipid content found in the bioflocs $(03.3-04.2 \mathrm{~g} / \mathrm{kg})$ is lower than the $125.0 \mathrm{~g} / \mathrm{kg}$ of lipids in the bioflocs obtained in a culture performed by McIntosh et al. (2000) but does not differ as markedly from the contents reported by Tacon (2000), Wasielesky et al. (2006), and Ju et al. (2008), who also found relatively low quantities of lipids in bioflocs $(06.0,05.0$, and $12.0-23.0 \mathrm{~g} / \mathrm{kg}$, respectively). This variation is most likely related to differences in the microbial composition and culture conditions of the bioflocs. A clearly increasing trend in the ash content of the bioflocs with increasing salinity (13.4-44.5 g/kg at 4-32\%, respectively) was demonstrated. These results are consistent with the observations of Ju et al. (2008) that the ash content of bioflocs increased with increasing salinity.

\section{Conclusions}

The increase in salinity from 4 to $32 \%$ and its arising effects, like the increase in alkalinity and total suspended solids concentration, positively affect the growth performance and survival of $L$. vannamei juveniles reared in super-intensive system without water exchange. The shrimp body composition is also influenced, with highest body lipid concentration found at $32 \%$.

\section{References}

APHA - American Public Health Association. 1989. Standard methods for the examination of water and waste water. Washington, USA.

Aminot, A. and Chaussepied, M. 1983. Manuel des analyses chimiques em milieu marin. CNEXO, Brest.

AOAC - Association of Official Analytical Chemists. 1999. Official methods of analysis. 16th ed. Washington, USA.

Atwood, H. L.; Young, S. P.; Tomasso, J. R. and Browdy, C. L. 2003. Survival and growth of pacific white shrimp Litopenaeus vannamei postlarvae in low-salinity and mixed-salt environments. Journal of the World Aquaculture Society 34:518-523.

Avnimelech, Y. 1999. Carbon/nitrogen ratio as a control element in aquaculture systems. Aquaculture 176:227-235.

Avnimelech, Y. 2007. Feeding with microbial flocs by tilapia in minimal discharge bio-flocs technology ponds. Aquaculture 264:140-147.

Ballester, E. L. C.; Abreu, P. C.; Cavalli, R. O.; Emerenciano, M.; Abreu, L. and Wasielesky, W. 2010. Effect of practical diets with different protein levels on the performance of Farfantepenaeus paulensis juveniles nursed in a zero exchange suspended microbial flocs intensive system. Aquaculture Nutrition 16:163-172.

Boyd, C. E. 1989. Water quality management and aeration in shrimp farming. 2nd ed. Alabama Fisheries and Allied Aquacultures Departmental. Agricultural Experiment Station. Auburn University, Alabama, USA.

Boyd, C. E. 2001. Inland shrimp farming and the environment. Journal of the World Aquaculture Society 32:10-12.

Boyd, C. E. 2007. Phosphorus: Key to phytoplankton management. Global Aquaculture Advocate July-August:62-64.

Burford, M. A.; Thompson, P. J.; Bauman, R. H. and Pearson, D. C. 2004. The contribution of flocculated material to shrimp Litopenaeus vannamei nutrition in a high-intensive zero-exchange system. Aquaculture 232:525-537.

Chamberlain, G.; Avnimelech, Y.; McIntosh, R. P. and Velasco, M. 2001. Advantages of aerated microbial reuse systems with balanced C:N: Composition and nutritional value of organic detritus. The Advocate June:22-24.

Cheng, K. M.; Hu, C. Q.; Liu, Y. N.; Zheng, S. X. and Qi, X. J. 2005. Dietary magnesium requirement and physiological responses of marine shrimp Litopenaeus vannamei reared in low salinity water. Aquaculture Nutrition 11:385-393.

Cheng, K. M.; Hu, C. Q.; Liu, Y. N.; Zheng, S. X. and Qi, X. J. 2006. Effects of dietary calcium, phosphorus and calcium/phosphorus ratio on the growth and tissue mineralization of Litopenaeus vannamei reared in low-salinity water. Aquaculture 251:472-483.

Cohen, J.; Samocha, T. M.; Fox, J. M.; Gandy, R. L. and Lawrence, A. L. 2005. Characterization of water quality factors during intensive raceway production of juvenile Litopenaeus vannamei using limited discharge and biosecure management tools. Aquacultural Engineering 32:425-442.

Davis, D. A.; Boyd, C. E.; Rouse, D. B and Saoud, I. P. 2005. Effects of potassium, magnesium, and age on growth and survival of Litopenaeus vannamei post-larvae reared in inland low salinity well waters in west Alabama. Journal of the World Aquaculture Society 36:403-406.

Decamp, O.; Cody, J.; Conquest, L.; Delanoy, G. and Tacon, A. G. J. 2003. Effect of salinity on natural community and production of 
Litopenaeus vannamei (Boone) within experimental zero-water exchange culture systems. Aquaculture Research 34:345-355.

Gómez-Jiménez, S.; González-Félix, M. L.; Perez-Velazquez, M.; Trujillo Villalba, D. A.; Esquerra-Brauer, I. R. and BarrazaGuardado, R. 2005. Effect of dietary protein level on growth, survival and ammonia efflux rate of Litopenaeus vannamei (Boone) raised in a zero water exchange culture system. Aquaculture Research 36:834-840.

Gross, A.; Abutbul, S. and Zilberg, D. 2004. Acute and chronic effects of nitrite on white shrimp Litopenaeus vannamei cultured in lowsalinity brackish water. Journal of the World Aquaculture Society 35:315-321.

Hakanson, L. 2006. The relationship between salinity, suspended particulate matter and water clarity in aquatic systems. Ecological Research 21:75-90.

Hopkins, J. S.; Sandifer, P. A. and Browdy, C. L. 1995. Effect of two feed protein levels and feed rate combinations on water quality and production of intensive shrimp ponds operated without water exchange. Journal of the World Aquaculture Society 26:93-97.

Huang, K.; Wang, W.; Lu, J.; Dai, X. W. and Zhou, J. N. 2004. Salinity effects on growth and biochemical composition of Litopenaeus vannamei. Marine Science 28:20-25.

Jayasankar, V.; Jasmani, S.; Nomura, T.; Nohara, S.; Huong, D. T. T. and Wilder, M. N. 2009. Low salinity rearing of the Pacific White Shrimp Litopenaeus vannamei: Acclimation, survival and growth of postlarvae and juveniles. Japan Agricultural Research Quarterly 43:345-350.

Jiang, D. H.; Lawrence, A. L.; Neil, W. H. and Gong, H. 2000. Effects of temperature and salinity on nitrogenous excretion by Litopenaeus vannamei juveniles. Journal of Experimental Marine Biology and Ecology 253:193-209.

Ju, Z. Y.; Forster, I.; Conquest, L.; Dominy, W.; Kuo, W. C. and Horgen, F. D. 2008. Determination of microbial community structures of shrimp floc cultures by biomarkers and analysis of floc amino acid profile. Aquaculture Research 39:118-133.

Kuhn, D. D.; Boardman, G. D.; Craig, S. R.; Flick, G. J. and McLean, E. 2008. Use of microbial focs generated from tilapia effluent as a nutritional supplement for shrimp Litopenaeus vannamei in recirculating aquaculture systems. Journal of the World Aquaculture Society 39:72-82.

Laramore, S.; Laramore, C. R. and Scarpa, J. 2001. Effect of low salinity on growth and survival of postlarvae and juvenile Litopenaeus vannamei. Journal of the World Aquaculture Society 32:385-392.

Li, E.; Chen, L.; Zeng, C.; Chen, X.; Yu, N.; Lai, Q. and Qin, J. G. 2007. Growth, body composition, respiration and ambient ammonia nitrogen tolerance of the juvenile white shrimp Litopenaeus vannamei at different salinities. Aquaculture 265:385-390.

Liang, M.; Wang, S.; Wang, J.; Chang, Q. and Mai, K. 2008. Comparison of flavor components in shrimp Litopenaeus vannamei cultured in sea water and low salinity water. Fisheries Science 74:1173-1179.

Lin, Y. C. and Chen, J. C. 2003. Acute toxicity of nitrite on Litopenaeus vannamei (Boone) juveniles at different salinity levels. Aquaculture 224:193-201.

Maicá, P. F.; Borba, M. R and Wasielesky, W. 2012. Effect of low salinity on microbial floc composition and performance of Litopenaeus vannamei (Boone) juveniles reared in a zero-waterexchange super-intensive system. Aquaculture Research 43:361-370.

Marchiori, A. M. 1996. Guia ilustrado de maturação e larvicultura do camarão-rosa Penaeus paulensis Perez-Farfante. Universidade Federal do Rio Grande, Rio Grande.

McAbee, B. J.; Browdy, C. L.; Rhodes, R. J. and Stokes, A. D. 2003. Greenhouse raceway: Considered for superintensive U.S. shrimp production. The Advocate June:40-43.
McGraw, W. J.; Davis, D. A.; Teichert-Coddington, D. and Rouse, D. B. 2002. Acclimation of Litopenaeus vannamei postlarvae to low salinity: Influence of age, salinity endpoint and rate of salinity reduction. Journal of the World Aquaculture Society 33:78-84.

McIntosh, B. J.; Samocha, T. M.; Jones, E. R.; Lawrence, A. L.; McKee, D. A.; Horowitz, S. and Horowitz, A. 2000. The effect of a bacterial supplement on the high-density culturing of Litopenaeus vannamei with low-protein diet on outdoor tank system and no water exchange. Aquacultural Engineering 21:215-227.

Moya, M.; Lawrence, A. L.; Collins, C. A. and Samocha, T. M. 1999. Acclimation of Penaus vannamei postlarvae to $2 \mathrm{ppt}$ ground saline water in Sonora Desert, Arizona. p.424 (abstr.). In: World Aquaculture. World Aquaculture Society, Baton Rouge, LA.

Naylor, R. L.; Goldburg, R. J.; Mooney, H.; Beveridge, M.; Clay, J.; Folke, C.; Kautsky, N.; Lubchenco, J.; Primavera, J. and Williams, M. 1998. Nature's subsidies to shrimp and salmon farming. Science 282:883-884.

Perez-Velazquez, M.; Gonzáléz-Félix, M. L.; Jaimes-Bustamente, F.; Martínez-Córdova, L. R.; Trujillo-Villalba, D. A. and Davis, D. A. 2007. Investigation of the effects of salinity and dietary protein level on growth and survival of pacific white shrimp Litopenaeus vannamei. Journal of the World Aquaculture Society 38:475-485.

Perez-Velazquez, M.; González-Félix, M. L.; Gómez-Jiménez, S.; Davis, D. A. and Miramontes-Higuera, N. 2008. Nitrogen budget for a low-salinity zero water exchange culture system: II. Evaluation of isonitrogenous feeding of various dietary protein levels to Litopenaeus vannamei (Boone). Aquaculture Research 39:995-1004.

Perez-Velazquez, M.; Allen Davis, D.; Roy, L. A. and González-Félix, M. L. 2012. Effects of water temperature and $\mathrm{Na}^{+}: \mathrm{K}^{+}$ratio on physiological and production parameters of Litopenaeus vannamei reared in low salinity water. Aquaculture 342:13-17.

Ponce-Palafox, J.; Martinez-Palacios, C. A. and Ross, L. G. 1997. The effects of salinity and temperature on the growth and survival rates of juvenile white shrimp Penaeus vannamei (Boone) 1931. Aquaculture 157:107-115.

Radchenko, I. G. and Il'yash, L.V. 2005. Growth and photosynthetic activity of diatom Thalassiosira weissflogii at decreasing salinity. Plant Physiology 33:242-247.

Rosas, C.; Cuzon, G.; Gaxiola, G.; Priol, Y. L.; Pascual, C.; Rossignyol, J.; Contreras, F.; Sanchez, A. and Wormhoudt, A. V. 2001. Metabolism and growth of juveniles of Litopenaeus vannamei: Effect of salinity and dietary carbohydrate levels. Journal of Experimental Marine Biology and Ecology 259:1-22.

Roy, L. A.; Davis, D. A.; Saoud, I. P. and Henry, R. P. 2007. Effects of varying levels of aqueous potassium and magnesium on survival, growth, and respiration of the Pacific white shrimp, Litopenaeus vannamei, reared in low salinity waters. Aquaculture 262:461-469.

Saoud, I. P.; Davis, D. A. and Rouse, D. B. 2003. Suitability studies of inland well waters for Litopenaeus vannamei culture. Aquaculture 217:373-383.

Shiau, S. Y. 1998. Nutrient requirements of penaeid shrimp. Aquaculture 164:77-93.

Sokal, R. R. and Rohlf, F. J. 1969. Biometry - The principles and practices of statistics in biological research. W. H. Freeman and Co., San Francisco, CA, USA.

Strickland, J. D. H. and Parsons, T. R. 1972. A practical handbook of seawater analysis. Fishery Research Board, Ottawa, Canada.

Tacon, A. G. J. 2000. Shrimp feeds and feeding regimes in zeroexchange outdoor tanks. The Advocate April:15-16.

Timmons, M. B.; Ebeling, J. M.; Wheaton, F. W.; Summerfelt, S. T. and Vinci, B. J. 2002. Recirculating Aquaculture Systems. 2nd ed. Cayuga Aqua Ventures, New York, USA. 
UNESCO. 1983. Chemical methods for use in marine environmental monitoring. Manual and guides. 12th ed. Intergovernamental Oceanographic Commissiony, Paris, France.

Van Wyk, P. and Scarpa, J. 1999. Water quality and management. p.128-138. In: Farming marine shrimp in recirculating freshwater systems. Van Wyk, P. et al., eds. Florida Department of Agriculture and Consumer Services, Tallahassee, FL, USA.

Walker, S. J.; Neill, W. H.; Lawrence, A. L. and Gatlin, D. M. 2009. Effect of salinity and body weight on ecophysiological performance of the Pacific white shrimp (Litopenaeus vannamei). Journal of Experimental Marine Biology and Ecology 380:119-124.

Wasielesky, W.; Atwood, H.; Stokes, A. and Browdy, C. L. 2006. Effect of natural production in a zero exchange suspended microbial floc based super-intensive culture system for white shrimp Litopenaeus vannamei. Aquaculture 258:396-403.

Wyban, J.; Walsh, W. A. and Godin, D. M. 1995. Temperature effects on growth, feeding rate and feed conversion of the Pacific white shrimp (Penaeus vannamei). Aquaculture 138:267-279. 